\title{
Literature Learning: Pragmatic Study of Humor Discourse in Indonesian Political Humor Book
}

\author{
Santi Wahyufi Diningsih ${ }^{1}$, Andayani ${ }^{2}$, Muhammad Rohmadi ${ }^{3}$
}

\begin{tabular}{lr}
\multicolumn{2}{l}{ ARTICLE INFO } \\
\hline Article History: \\
Received & 03.04 .2019 \\
Received & in revised \\
form & 19.08 .2019 \\
Accepted & \\
Available online \\
01.11.2019
\end{tabular}

INTRODUCTION

Language is defined as a communication tool among community members in the form of sound symbols produced by human speech organ. Every sound produced cannot be considered a language if it is meaningless (Devianty, 2017). If language is seen as a system, then we need to look at its components and their interactions (Andrason, 2014; Gromov \& Migrina, 2017; Taverniers, 2011). The components consist of substance, form and meaning. Substance refers to sounds used in language, such as vowels and consonants. Forms can be grammar, lexis and phonology. Then, meaning refers to what is told in speaking a language. Just like other components, language also requires time and study and is used as a culture to keep developing (Rachman, Andayani, \& Suyitno, 2019; Ulrich \& Jr., 2018). However, in this study the use of language refers to more scientific things in nature.

Scientific studies no longer discuss how language is defined as a communication tool among community members (Santana, 2016), but the use of objects from language as a material to be studied and how the object should be studied. Linguists and philosophers have given the limitation in the language conception, namely: (1) Exist, observable, (2) describable, and (3) recognized as a language. One object of language is the use of discourse.

Discourse in pragmatic studies is interpreted as a coherent combination of sentences from a speaker to a listener including speech and context (Adjei, 2013; Wang, 2014) Discourse can be used in various fields

\footnotetext{
${ }^{1}$ Corresponding e-mail: santiwahyufidiningsih401@gmail.com, orcid.org/0000-0002-2933-0009

2 orcid.org/0000-0002-5233-805X

orcid.org/0000-0001-5216-0805

Sebelas Maret University, Surakarta, Indonesia ${ }^{123}$
}

Keywords: ${ }^{1}$

(C) IJERE. All rights reserved

Humor Book, Descriptive, Language Game, Pragmatic, Discourse. \begin{abstract}
The use of discourse as a medium for conveying messages to the community has is often conveyed in with humorous attributes to make it more interesting. This Politik Indonesia (Indonesian Political Humor)" book. The qualitative approach showed that the pragmatic aspects contained in the book were in the form of presuppositions and implicature aspects. The presupposition aspect includes lexical, counterfactual, structural presuppositions. For the implicature aspect is in the form of mockery and satirical forms of implicatures. These results prove that the pragmatic aspects used in humor discourse are discourse constructors to discourse that contains aspects of pragmatics can be used as teaching materials th learning Indonesian in senior high schools. This relates to Basic Competence have.
\end{abstract}


(Green, 1983). Educational studies have used discourse as a tool for assessment (Bryant, Spencer, \& Ferguson, 2016). In their study, Rijt, Swart, \& Coppen, (2018) use discourse as a tool for learning grammar and Alvermann (2009) uses discourse as a means to redesign teacher education programs in order that prospective teachers can build their own capacities according to their desired competencies. Discourse can also be built alone by students after learning a concept, because by which students can train their writing skills (Darsono, Winarno, \& Slamet, 2018; Markamah, Slamet, Rukayah, \& Winarni, 2019).

The use of discourse in the field of journalism is mostly done to convey facts to the public (Ekdale, 2014; Krüger, 2016; Sabao, 2016). The use of discourse is also widely spread in the political field (Councilor, 2017; Hart, 2015; Musolff, 2018; Roderick \& Roderick, 2018). The flexibility of the discourse to communicate various fields is undoubted. However, in order that the delivery is easily accepted by the community, discourse is often presented with attributes that make it more interesting, one of which is humor. Thus, such linguistic object is called humor discourse. In addition, each adaptability is reflected in individual skills to be flexible in cultures that are not well known in intercultural communication.

An understanding of humor is important because it covers many aspects of human life (Sakaeva et al., 2017). In the deteriorating situation of society, humor plays a very big role. One of the roles of humor in people's lives is to melt away and refresh the situation so as to relieve the tensions that arise due to living conditions (Rossing, 2016). Therefore, nowadays, there is an increase in the use of humor. Many types of humor appear in the community such as comics, memes, movie humors, stand-up comedy, and others that can be found around us (Puri, 2019). Besides its function of changing one's emotional situation, humor also has a function as a means of education and social criticism (Mata-mcmahon, 2017; Thorogood, 2016). As one of the linguistic phenomena, humor can be found in various places in various forms. Humor discourse can be presented in various media both printed and electronic media that can be accessed online (Vivona \& Ed, 2014).

Humor discourse in pragmatics itself is interpreted as a form of language that deviates from language rules and conversational principles. Humor can basically be created through stimulation or jokes by using language with certain methods. In addition to humor discourse, language games are also offten used in puns (Wijana, 2003). The most common deviation is in the form of the use of force (ambi-guity). Therefore, language games are needed to trigger humor discourse. Language games in this study are not those used in the language learning process in the classroom but are a form of language creativity by utilizing linguistic aspects.

Humor has been recommended as a good way for students to learn vocabulary, syntax, semantics, and discourse conventions of target languages, as well as to gain insight about (Bell, 2009). To help language teachers make a sense of humor and choose examples that are suitable for use in their classrooms, appropriate humor discourse studies are needed. This is in line with research department, namely Indonesia Language Education where the researcher is a teacher candidate who will teach Indonesian Language subjects. This study aims to examine humor discourse through a pragmatic approach, so that the results can be used by the teacher in the learning process in class.

\section{Situation of the Problem}

Studies on humor discourse have been conducted by several researchers, but in general the studies used are semantic and phonological approaches (Alduais, 2015; Gridina, 2016; Xiang, Grove, \& Giannakidou, 2016). If studied more deeply, humor discourse can be analyzed using pragmatic studies. Therefore, language games that are used as constructor aspects of humor discourse can be analyzed which will automatically produce new findings and enrich the studies on pragmatics.

\section{Aim of the Study}


In particular, this study aims to analyze humor discourse on books by using a pragmatic approach to provide an understanding of how the humor discourses seen from the language games used. The results of this study are expected to be used as a learning resource for student materials and reference source for the preliminary study of humor for teachers. This shows that system developed by Indonesia, both from the central level and the local of education, is able to synergize according to its era (Ardiansyah, Suharno \& Triyono, 2018).

\section{METHOD}

This study uses a qualitative approach and descriptive method. According to Creswell (2012), qualitative study is a method for exploring and understanding the meaning of a number of individuals or groups of people who come from social or humanitarian problems. Creswell (2012) also explained that qualitative methodology can be carried out with various approaches including: participatory research, discourse analysis, ethnography, grounded theory, case studies, phenomenology, and narrative. The choice of method in this study was adjusted to the research objectives. The formulation of the problem in this study is what pragmatic aspects are used in humor discourse in Indonesian political humor books?

\section{Material}

The data sources used in this study are humor discourses obtained from a book entitled Humor Politik Indonesia by Felicia NS in 2012 published by the Presindo Media in Tangerang. The data in this study were descriptive data in the form of words obtained from the results of analysis of language games from the pragmatic aspect in the Humor Politik Indonesia book. The book was selected using the analysis with several considerations based on theoretical concepts possessed by the researcher to provide descriptions of empirical characteristics.

\section{Data Analyzes}

This study focuses on language game in the pragmatic context in a humor book entitled Humor Politik Indonesia. The language game data found were then classified according to the division of their respective pragmatic aspects.

\section{FINDINGS}

This study used a pragmatic study. This study defines the hidden meaning of a writer (Siddiqui, 2018). In this case, pragmatics is a study that discusses how readers examine meaning. Pragmatic studies have several aspects, namely presupposition, speech acts, and conversational implicature. Each aspect is described in Table 1 as follows.

Table 1. Form of pragmatic study aspect

\begin{tabular}{|l|l|l|}
\hline No & \multicolumn{1}{|c|}{ Aspect } & \multicolumn{1}{|c|}{ Description } \\
\hline 1 & Presupposition & $\begin{array}{l}\text { The phenomenon where the speaker marks linguistically } \\
\text { or the initial assumption of the speaker before making a } \\
\text { speech that what will be conveyed is also understood by } \\
\text { the interlocutor. Expressions from the interlocutor that } \\
\text { carry presuppositions are called "presupposition triggers" }\end{array}$ \\
\hline 2 & Speech act & $\begin{array}{l}\text { Speech acts are usually performed by a speaker when } \\
\text { he/she begins to mark something that is part of social } \\
\text { interaction. Speech acts are carried out to make the } \\
\text { listener know the meaning of a sentence. Thus, speech } \\
\text { acts are very dependent on the context and place of } \\
\text { occurrence }\end{array}$ \\
\hline
\end{tabular}




\begin{tabular}{|l|l|l|}
\hline 3 & Conversational implicature & $\begin{array}{l}\text { Implicit messages contained in oral and written } \\
\text { expressions. This is closely related to what is interpreted, } \\
\text { suggested and intended. }\end{array}$
\end{tabular}

This study used Humor Politik Indonesia book so that the second aspect in Table 1 cannot be observed. In the next section, the author will present two other pragmatic aspects, namely Presupposition and Implicature.

\section{RESULT, DISCUSSION, AND SUGGESTIONS}

\section{Presupposition}

In pragmatic studies, the presupposition aspect can help listeners or readers in designing linguistic messages based on assumptions about something they have already known. By understanding the intent of speech or text, the communication process becomes smooth. Crane (1981) suggests that presupposition refers to conditions that must be found in the expected sequence of a sentence to be received appropriately. In addition, O'Grady, William, \& Dobrovolsky (1993) also suggest that presuppositions are assumptions or beliefs implied by the language user on certain words or structures.

Pragmatic presuppositions aspects contained in humor discourse of the Humor Politik Indonesia book by Felicia N S are presented in Table 2.

Table 2. Presupposition aspects contained in the Humor Politik Indonesia book

\begin{tabular}{|c|c|c|}
\hline Data & Presupposition aspects & Discussion \\
\hline 1 & $\begin{array}{l}\text { "A Farm Worker, a Conglomerate and a General" } \\
\text { Three brothers were mentioned: a farm worker, a } \\
\text { conglomerate and a general. The conglomerate invited } \\
\text { them to dinner at a well-known restaurant in Jakarta. } \\
\text { But they arrived a little late. As soon as they entered the } \\
\text { restaurant, a waiter politely met them. The waiter said } \\
\text { that the restaurant was almost closed because of } \\
\text { running out of raw materials. "Sorry we lack imported } \\
\text { meat," said the waiter. What the servant said was } \\
\text { responded differently. } \\
\text { - Farm worker: "What is imported meat?" } \\
\text { - Conglomerate: "What is lack?" } \\
\text { - General: "What is sorry? }\end{array}$ & $\begin{array}{l}\text { The presupposition that occurs in } \\
\text { data } 1 \text { is a lexical presupposition. Oualif } \\
\text { (2017) reveals that lexical } \\
\text { presuppositions are understood as a } \\
\text { form of presupposition when } \\
\text { conventionally stated meanings are } \\
\text { interpreted with separate phrases. This } \\
\text { lexical presupposition includes verbs, } \\
\text { restrictive expressions, iterative and so } \\
\text { on (Liang \& Liu, 2016). }\end{array}$ \\
\hline 2 & $\begin{array}{l}\text { "The relationship between the Five Principles } \\
\text { (Pancasila) and the } 1945 \text { Constitution" } \\
\text { In a P-4 upgrading on a campus, a speaker was } \\
\text { confused to see the participants drowsy. For ice } \\
\text { breaking, he decided to have a question and answer } \\
\text { session by appointing students randomly. First question, } \\
\text { - "What is the relationship between Pancasila and } \\
\text { the } 1945 \text { Constitution?" (Nobody answered). } \\
\text { - The speaker immediately pointed to a student } \\
\text { - sitting in the back corner. } \\
\text { Rizal replied immediately, "It's fine, Sir." }\end{array}$ & $\begin{array}{l}\text { The presupposition that occur in data } \\
2 \text { is the counterfactual presupposition. } \\
\text { Counterfactual presuppositions are not } \\
\text { only incorrect, but also the opposite of } \\
\text { the correct or contrary to reality (Oktoma } \\
\text { \& Mardiyono, 2013). This can be seen } \\
\text { from the speaker's serious question } \\
\text { answered incorrectly (jokingly) by Rizal. } \\
\text { The presupposition causes the humor } \\
\text { aspect of the discourse. }\end{array}$ \\
\hline
\end{tabular}




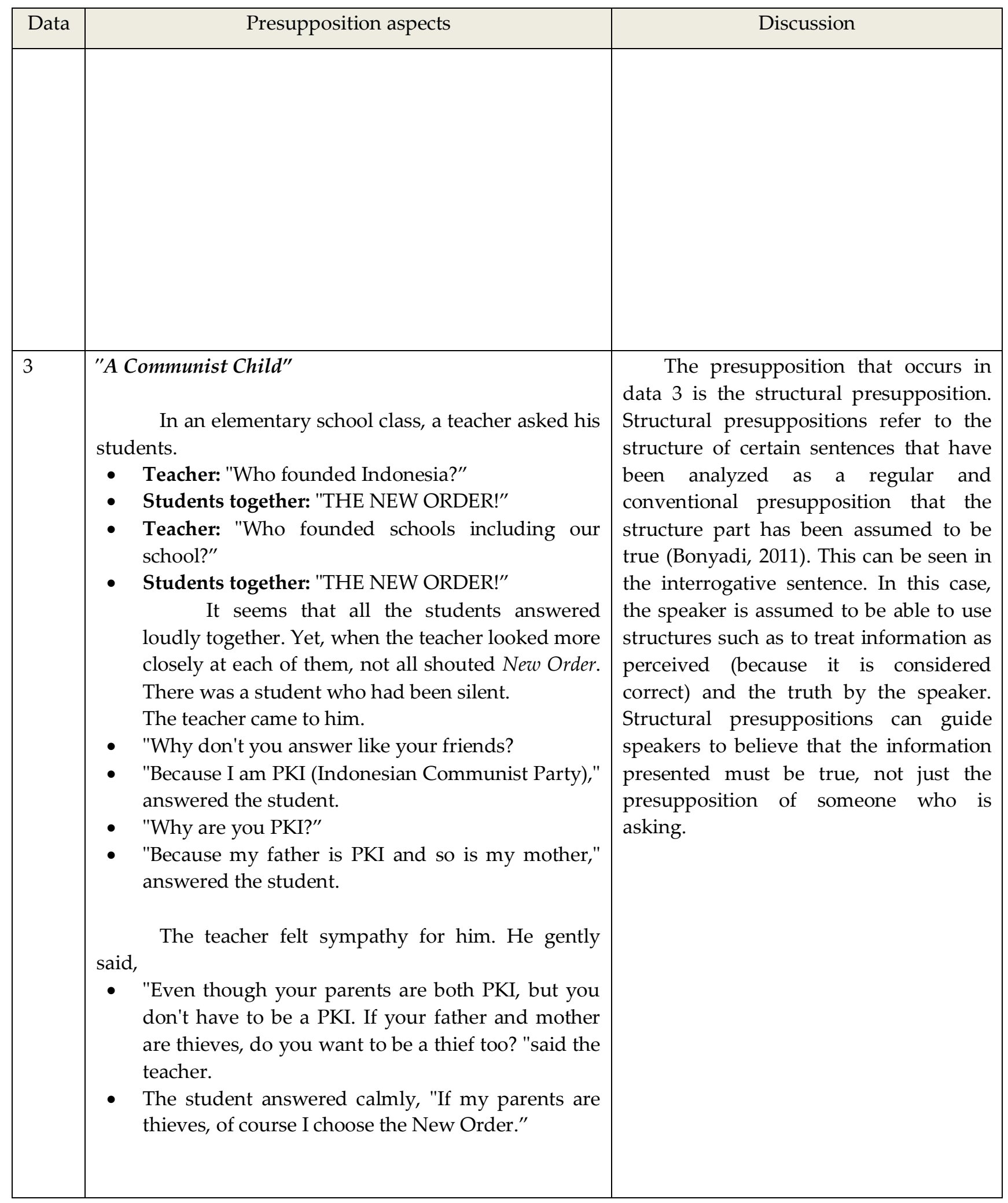

\section{Implicature}

Implicature is a proposition that implies the utterance of a sentence in a context even though the proposition is not part of what is actually said (Gerald Gazdar, 1979). In detail, implicature is a component of the speaker's meaning which has an aspect of what is meant in the speaker's speech without being part of what he says. In other words, implicature has a hidden purpose from a speech. The implicature aspects of the Humor Politik Indonesia book are presented in Table 3.

Table 3. Implicature aspects found in the Humor Politik Indonesia book 


\begin{tabular}{|c|c|c|}
\hline Data & Implicature aspects & Discussion \\
\hline 1 & $\begin{array}{l}\text { "Got you!" } \\
\text { Mamat, the evicted victim of the New Order ruler, } \\
\text { has just worked as a low employee at the post office. He } \\
\text { seemed to really enjoy his work. } \\
\text { But three days later, he was fired by his boss } \\
\text { because he was too passionate about stamp printing. } \\
\text { Five stamps had broken up. He has even caused the } \\
\text { stamped metal defect because every time he saw a } \\
\text { stamp with a picture of someone wearing a cap, Mamat } \\
\text { immediately beat him with a stamp as hard as possible, } \\
\text { while shouting "GOT YOU!!" }\end{array}$ & $\begin{array}{l}\text { The implication found in data } 1 \text { is } \\
\text { a mockery implicature. There is an } \\
\text { attitude of displeasure with other } \\
\text { characters to vent it. The low employee } \\
\text { did whatever he wanted when he saw a } \\
\text { picture of a figure he disliked. }\end{array}$ \\
\hline 2 & $\begin{array}{l}\text { "Wall Clock in Hell" } \\
\text { After the doomsday, a group of former rulers in } \\
\text { the world were waiting in line for their turn to enter the } \\
\text { gate of hell. They were called in one by one by the angel } \\
\text { in charge there. On the back wall, hung dozens of wall } \\
\text { clocks as seen at airports to show different time } \\
\text { positions throughout the world. Strangely, the wall } \\
\text { clocks near the gate of hell varied in speed. } \\
\text { A ruler from a small country in Europe was } \\
\text { confused. He asked the angel. } \\
\text { - The angel replied, "These clocks show your level of } \\
\text { honesty when in power. The more honest you are, } \\
\text { the more slowly it rotates. The more corrupt, the } \\
\text { faster it rotates. For example, let's look at the } \\
\text { Philippine clock. " } \\
\text { Ferdinand Marcos, the former ruler of the } \\
\text { Philippines, immediately turned pale. "The } \\
\text { Philippine clock is rotating fast. That means it's true } \\
\text { that Marcos committed a lot of corruptions," said } \\
\text { the angel. } \\
\text { - There, look at the yellow one," someone shouted } \\
\text { loudly, "Where is the clock from? The rotation is } \\
\text { faster than the clock from the Philippines." } \\
\text {-Oh, it's a clock from Congo," said the angel. "No } \\
\text { wonder that the clock rotates no less quickly than } \\
\text { the Philippine clock. Mobutu Sesesejo is famous for } \\
\text { being corrupt. " } \\
\text { countries. They searched for a clock from Indonesia. } \\
\text { After long searching and not finding any, one of } \\
\text { them dared himself to ask the angel. } \\
\text { "Oh, Indonesian clock ..., said the angel, smiling }\end{array}$ & $\begin{array}{l}\text { The implication in data } 2 \text { is the } \\
\text { sarcastic implicature. This is supported } \\
\text { by the presence of speech findings in the } \\
\text { form of satire addressed to the leaders of } \\
\text { the people that everything done in this } \\
\text { world will be paid in the hereafter. }\end{array}$ \\
\hline
\end{tabular}




\begin{tabular}{|c|c|c|}
\hline Data & Implicature aspects & Discussion \\
\hline & $\begin{array}{l}\text { amusedly. "We put it in the kitchen. Very suitable to } \\
\text { be a fan! }\end{array}$ & \\
\hline 3 & $\begin{array}{l}\text { "A Policeman, an Army, and an Intel" } \\
\text { Police, Army, and Intelligence Agency boasted } \\
\text { to each other that they were the best in arresting } \\
\text { suspected terrorists. The government believed that it } \\
\text { was necessary to do a test to find out who was the best. } \\
\text { Each party sent their greatest team. A rabbit was } \\
\text { released into the forest. The participants had to try to } \\
\text { catch it. The winner was the one who could catch the } \\
\text { first. } \\
\text { The intelligence team entered the forest. They } \\
\text { immediately put informants in every corner of the } \\
\text { forest. They questioned every shrub, grass, insect, and } \\
\text { all the animals in the forest. No forest dwellers were not } \\
\text { interrogated. After one month of thorough and } \\
\text { extensive forest investigation, the intelligence team } \\
\text { finally concluded that the rabbit had never existed, aka } \\
\text { only bird news. } \\
\text { The army team entered the forest. After one } \\
\text { month of working without success, they finally lost their } \\
\text { temper and burned the forest. Then, they reported that } \\
\text { the rabbit had been destroyed. The "to catch" command } \\
\text { has been interpreted as "annihilating", so the } \\
\text { government considered it a procedural error. The army } \\
\text { team failed to be the winner. Finally, the police team } \\
\text { entered the forest. Only in two hours, they had come out } \\
\text { of the forest carrying a white mouse. Its body was } \\
\text { injured. Apparently, it had been interrogated while } \\
\text { being tortured. The white mouse shouted, "Yes ... yes, I } \\
\text { confess ... I confess. I'm not a white mouse. I'm a rabbit." }\end{array}$ & $\begin{array}{l}\text { The implication in data } 3 \text { is the } \\
\text { sarcastic implicature. This is supported } \\
\text { by the utterance that a white mouse is a } \\
\text { domestic corrupter. No matter how } \\
\text { smart they lie, they will be found out too. }\end{array}$ \\
\hline
\end{tabular}

The humor discourse is characterized by elements of humor to genuinely create a happy mood. In addition to conveying the intention to entertain the reader, the author also expressed criticism to other parties, causing indirect effects.

Linguistic researchers have paid attention to the study of humor discourse, as evidenced by several studies that examine humor, its meaning and the way to make it. Study Result

Hassan (2013) shows that humor is a complex cultural phenomenon. Thus, to create a humor, it is necessary to do a survey of the main theories to see the uniformity of ideas to be conveyed with humor attributes. This is in accordance with the book analyzed by the author. The Humor Politik Indonesia is packaged by considering theories that are understood by ordinary people so that with the presentation of humor attributes, the reader will find it easier to accept it. In addition, the study of Verschueren (2017) shows that 
stories with very serious themes can be presented in the form of humor. However, Sinkeviciute (2014) limits that the use of humor should not be too much because it will fade the intent of the real writer.

Based on the results of the analysis on the Humor Politik Indonesia book, it can be concluded that the humor constructor in the book uses presupposition and implicature aspects. The use of presuppositions is in the form of expressions relating to the conventional word meaning, something that is contrary to reality or counterfactual and structural sentences. Then, from the implicature aspect is in the form of satire and mockery implicatures for the analysis results obtained 3 presupposed data and 3 implicature data.

Language teachers are often encouraged to use humor in class. Humor is presented as a social and psychological benefit for students. It helps calm them down to create a comfortable classroom atmosphere, to create bonds between classmates, to increase student interest, and only to make learning more enjoyable. In addition, humor has been recommended as the best way for students to learn vocabulary, syntax, semantics, and conventions of target language discourse, as well as to gain insight into the culture of those who speak the language (Bell, 2009). To help language instructors create a sense of humor and choose suitable examples for use in their classrooms, a suitable study of humor discourse is needed. The results of this study indicate that political humor discourse can be used as a humor material or study material for student learning.

The literature on the relationship between cognitive development and expressions of humor shows that the type of humor students enjoy demonstrates their stages of thinking. This cognitive process develops from finding humor in actions and languages that are inappropriate and contain various meanings. When students laugh by interpreting humor according to their cognitive stages, it shows that they understand the meaning contained in the humor. Teachers can learn a lot about the sophistication of students' knowledge by realizing what they think is funny. They can also foster the development of higher-order thinking processes, such as creativity and problem solving, and mastery of basic skills by encouraging the development of humor. The study concluded that the use of humor by teachers can increase students' attention, reduce test anxiety, enhance critical thinking, reading and writing skills, and promote a positive class climate (Bergen, 2012).

Many studies have been conducted on the use of humor in learning, such as the role of humor in physics learning (Berge, 2017), the use of verbal humor to build the closeness of the teacher with his students(Gorham \& Christophel, 1990), students' perceptions of humor used in learning(Melissa B. Wanzer, Frymier, \& Irwin, 2010; Melissa Bekelja Wanzer \& Frymier, 1999), humor used as a problem-based learning facility (Chauvet \& Hofmeyer, 2007), the relationship between humor and intelligence, creativity, and (Hauck \& Thomas, 1972) learning, and the use of humor in other learning activities (Dixon, Strano, Willingham, \& Chandler, 2011; Fisher, 1997; Mihalcea \& Strapparava, 2006; Shively, 2013; Wu, 2008; Ziv, 1988). This research, I hope to be able to add references for researchers and teachers, especially Indonesian subjects, which can be used as suggestions in the teaching and learning process.

Based on this study, it can be implied that humor discourse that contains pragmatic aspects of the Humor Politik Indonesia book can be used as a learning material for students. This is in accordance with the demands of Basic Competence in Indonesian Language subject in the tenth grade so that students can evaluate anecdotal texts from the aspect of implicit meaning. The pragmatic aspect of the presupposing and implicature can facilitate students to evaluate the implicit meaning in the humor text.

\section{REFERENCES}

Adjei, S. B. (2013). Discourse analysis: Examining language use in context. The Qualitative Report, 18(50), 1-10.

Alduais, A. M. S. (2015). An account of phonetics and phonology as similar identical or different. The International Journal of Indian Psychology, 3(1), 157-165.

Alvermann, D. E. (2009). Teaching preservice teachers to read the discourse of school reform. Pedagogies: An 
Diningsih,S.W. Andayani \& Muhammad Rohmadi, M.(2019). Literature learning: Pragmatic study of humor discourse in Indonesian political humor book. International Journal of Educational Research Review, Special Issue,680-690.

International Journal, 1(1), 67-75. https://doi.org/10.1207/s15544818ped0101

Andrason, A. (2014). Language complexity: An insight from complex-system theory. International Journal of Language and Linguistics, 2(2), 74-89. https://doi.org/10.11648/j.ijll.20140202.15

Ardiansyah, R , ., S , ., T . (2018). Inheritance national culture through learning in elementary school at disruptive era: Case study in Surakarta Indonesia. International Journal of Educational Research Review, 3 (4), 48-53. DOI: 10.24331/ijere.427917

Bell, N. D. (2009). Learning about and through humor in the second language classroom. Language Teaching Research, 13(3), 241-258. https://doi.org/10.1177/1362168809104697

Berge, M. (2017). The role of humor in learning physics: A study of undergraduate students. Research in Science Education, 47(2), 427-450. https://doi.org/10.1007/s11165-015-9508-4

Bergen, D. (2012). Teaching strategies: Using humor to facilitate learning. Childhood Education, 69(2), 105-106. https://doi.org/10.1080/00094056.1992.10520903

Bonyadi, A. (2011). Linguistic nature of presupposition in american and persian newspaper editorials. International Journal of Linguistics, 3(1), 1-4. https://doi.org/10.5296/ijl.v3i1.554

Bryant, L., Spencer, E. \& Ferguson, A. (2016). Clinical use of linguistic discourse analysis for the assessment of language in aphasia of language in aphasia. Aphasiology, 00(00), 1-22. https://doi.org/10.1080/02687038.2016.1239013

Chauvet, S., \& Hofmeyer, A. (2007). Humor as a facilitative style in problem-based learning environments for nursing students. Nurse Education Today, 27(4), 286-292. https://doi.org/10.1016/j.nedt.2006.05.008

Councilor, K. C. (2017). Communication and critical / cultural studies feeding the body politic: metaphors of digestion in Progressive Era US immigration discourse. Communication and Critical/Cultural Studies, 14(2), 139-157. https://doi.org/10.1080/14791420.2016.1274044

Creswell, J. W. (2012). Educational research: Planning, conducting, and evaluating quantitative and qualitative research. Educational Research (Vol. 4). https://doi.org/10.1017/CBO9781107415324.004

Darsono, Winarno, \& Slamet. (2018). The need textbook writing of children's story based on character education. International Journal of Educational Research Review, 3(2), 1-8. https://doi.org/10.24331/ijere.391780

Devianty, R. (2017). Bahasa Sebagai Cermin Kebudayaan. Jurnal Tarbiyah, 24(2), 226-245.

Dixon, P. N., Strano, D. A., Willingham, W., \& Chandler, C. K. (2011). Sense of humor as a mediator during incidental learning of humor-related material. Psychological Reports, 64(3), 851-855. https://doi.org/10.2466/pr0.1989.64.3.851

Ekdale, B. (2014). Slum discourse, media representations and maisha mtaani in Kibera, Kenya. African Journalism Studies, 35(1), 37-41. https://doi.org/10.1080/02560054.2014.886277

Fisher, M. S. (1997). The effect of humor on learning in a planetarium. Science Education, 81(6), 703-713. https://doi.org/10.1002/(SICI)1098-237X(199711)81:6<703:AID-SCE7>3.0.CO;2-M

Gerald Gazdar. (1979). Pragmatic implicature, preassuppasition and logical form. England: Academic Press.

Gorham, J., \& Christophel, D. M. (1990). The relationship of teachers' use of humor in the classroom to immediacy and student learning. Communication Education, 39(1), 46-62. https://doi.org/10.1080/03634529009378786

Gridina, N. (2016). Exploring meaning: verb semantics and quality. Journal of Language \& Education, 2(3), 4553. https://doi.org/10.17323/2411-7390-2016-2-3-45-53

Gromov, V. A., \& Migrina, A. M. (2017). A language as a self-organized critical system. Wiley Hindawi, (2), 17. 
Diningsih,S.W. Andayani \& Muhammad Rohmadi, M.(2019). Literature learning: Pragmatic study of humor discourse in Indonesian political humor book. International Journal of Educational Research Review, Special Issue,680-690.

Hassan, B. A. (2013). The pragmatics of humor: January 25th Revolution and Occupy Wall Street. Mediterranean Journal of Social Sciences, 4(2), 551-562. https://doi.org/10.5901/mjss.2013.v4n2p551

Hauck, W. E., \& Thomas, J. W. (1972). The relationship of humor to intelligence, creativity, and intentional and incidental learning. Journal of Experimental Education, 40(4), 52-55. https://doi.org/10.1080/00220973.1972.11011352

Krüger, F. (2016). Discourse ethics and the media. AF, 37(1), 21-39. https://doi.org/10.1080/23743670.2015.1129503

Liang, R., \& Liu, Y. (2016). An analysis of presupposition triggers in Hilary Clinton's first campaign speech. International Journal of English Linguistics, 6(5), 68. https://doi.org/10.5539/ijel.v6n5p68

Markamah, E. S., Slamet, Rukayah, \& Winarni, R. (2019). Developing appreciative literature textbook based on thematicintegrative through active learning. International Journal of Educational Research Review, 4(3), 395-402. https://doi.org/10.24331/ijere.573897

Mata-mcmahon, J. (2017). Spirituality and humour: Making connections for early childhood education. $\begin{array}{lllll}\text { International Journal of } & \text { Children's }\end{array}$ https://doi.org/10.1080/1364436X.2017.1287681

Mihalcea, R., \& Strapparava, C. (2006). Learning to laugh (automatically): Computational models for humor recognition. Computational Intelligence, 22(2), 126-142. https://doi.org/10.1111/j.1467-8640.2006.00278.x

Oktoma, E., \& Mardiyono, S. (2013). The analysis of presupposition in the short stories of silvester goridus sukur. English Review: Journal of English Education, 2(1), 1-11.

Oualif, M. (2017). Presupposition: A semantic or pragmatic phenomenon? Arab World English Journal, 8(3), 46-59. https://doi.org/10.24093/awej/vol8no3.4

Puri, A. D. (2019). Analysis of Humor on Cartoon Comics "Be Like Bro": Pragmatics Study. Journal of Pragmatics Research, 1(1), 13-22.

Rachman, I. F., Andayani, \& Suyitno. (2019). Cultural Issues in Indonesian Language Learning for Foreign Speakers. International Journal of Educational Research Review, 4(3), 454-460. https://doi.org/10.24331/ijere.573951

Rijt, J. Van, Swart, P. De, \& Coppen, P. (2018). Research papers in education linguistic concepts in L1 grammar education: A systematic literature review. Research Papers in Education, 1-28. https://doi.org/10.1080/02671522.2018.1493742

Rossing, J. P. (2016). American humor studies association a sense of humor for civic life toward a strong defense of humor. Stddies in American Humor, 2(1), 1-21.

Sabao, C. (2016). Arguments for an appraisal linguistic discourse approach to the analysis of 'objectivity' in 'hard' news reports arguments for an appraisal linguistic discourse approach to the analysis of 'objectivity' in 'hard' news reports. African Journalism Studies, 37(1), 40-63. https://doi.org/10.1080/23743670.2015.1095776

Sakaeva, L. R., Martynova, E. V, Salyahova, G. I., Sadekova, A. H., Khanipova, I., \& Studies, O. (2017). Sociolinguistics features of humor in american linguoculture. Journal of Fundamental and Applied Sciences, 9(7), 1224-1230.

Santana, C. (2016). What is language? Journal of Philosophy, 3(19), 501-523.

Shively, R. L. (2013). Learning to be funny in Spanish during study abroad: L2 humor development. Modern Language Journal, 97(4), 930-946. https://doi.org/10.1111/j.1540-4781.2013.12043.x

Siddiqui, A. (2018). The principle features of English pragmatics in applied linguistics. Advances in Language and Literary Studies ISSN: 9(2), 77-80.

Sinkeviciute, V. (2014). "When a joke's a joke and when it's too much": Mateship as a key to interpreting jocular FTAs in Australian English. Journal of Pragmatics, 60, 121-139. 
Diningsih,S.W. Andayani \& Muhammad Rohmadi, M.(2019). Literature learning: Pragmatic study of humor discourse in Indonesian political humor book. International Journal of Educational Research Review, Special Issue,680-690.

https://doi.org/10.1016/j.pragma.2013.11.004

Taverniers, M. (2011). The syntax-semantics interface in systemic functional grammar: Halliday's interpretation of the Hjelmslevian model of stratification. Journal of Pragmatics, 43(4), 1100-1126. https://doi.org/10.1016/j.pragma.2010.09.003

Thorogood, J. (2016). Satire and geopolitics: vulgarity, ambiguity and the body grotesque in south park. Geopolitics, 21(1), 215-235. https://doi.org/10.1080/14650045.2015.1089433

Ulrich, T. A., \& Jr., D. M. T. (2018). Free voluntary reading: A neglected strategy for language acquisition. Applied Language Learning, 28(2), 25-48.

Umar Nadeem, M , Mohammed, R, Dalib, S . (2018). An overview of dominant research approaches to measure intercultural communication competence (ICC). International Journal of Educational Research Review, 3 (4), 141-149. DOI: 10.24331/ijere.455333

Verschueren, J. (2017). The pragmatics of humor in a serious story. ELUA. Estudios de Lingüistica Universidad de Alicante, (31), 311-326. https://doi.org/10.14198/elua2017.31.16

Vivona, B. D., \& Ed, D. (2014). To laugh or not to laugh: Understandings of the appropriateness of humour and joking in the workplace. European Journal of Humour Research, 2(1), 1-18.

Wang, Y. (2014). A short analysis of discourse coherence. Jurnal of Language Teaching and Research, 5(2), 460465. https://doi.org/10.4304/jltr.5.2.460-465

Wanzer, Melissa B., Frymier, A. B., \& Irwin, J. (2010). An explanation of the relationship between instructor humor and student learning: Instructional humor processing theory. Communication Education, 59(1), 118. https://doi.org/10.1080/03634520903367238

Wanzer, Melissa Bekelja, \& Frymier, A. B. (1999). The relationship between student perceptions of instructor humor and students' reports of learning. Communication Education, 48(1), 48-62. https://doi.org/10.1080/03634529909379152

Wijana, I Putu. (2003). Permainan Bahasa dalam Rangka Meningkatkan Mutu Pengajaran Ilmu Bahasa Indonesia: Yogyakarta

Witczak-plisiecka, I. (2009). Speech acts and the autonomy of linguistic pragmatics. Loadz Paper in Pragmatics, 5(1), 85-106. https://doi.org/10.2478/v10016-009-0008-8

$\mathrm{Wu}$, S. R. (2008). Humor and empathy: Developing students' empathy through teaching robots to tell english jokes. Proceedings - 2nd IEEE International Conference on Digital Game and Intelligent Toy Enhanced Learning, DIGITEL 2008, 213-214. https://doi.org/10.1109/DIGITEL.2008.27

Xiang, M., Grove, J., \& Giannakidou, A. (2016). Semantic and pragmatic processes in the comprehension of negation: An event related potential study of negative polarity sensitivity. Journal of Neurolinguistics, 38 , 71-88. https://doi.org/10.1016/j.jneuroling.2015.11.001

Ziv, A. (1988). Teaching and learning with humor: Experiment and replication. Journal of Experimental Education, 57(1), 5-15. https://doi.org/10.1080/00220973.1988.10806492 